\title{
Removal of chromium and Iron using mixed adsorbent for synthetic and industrial samples in a continuous column reactor
}

\author{
Dr. Srinivas Tadepalli \\ College of Engineering, Dept of Chemical Engineering, Al Imam Islam University, Kingdom \\ of Saudi Arabia, Riyadh-11432 \\ Dr. K.S.R. Murthy* \\ Dept of Chemistry, University of Petroleum and Energy Studies, Dehradun-248007, \\ Uttarakhand-India \\ Dr. P. Suresh Kumar \\ Dept of Mechanical Engineering, University of Petroleum and Energy Studies, Dehradun- \\ 248007, Uttarakhand-India

\section{Dr. Prasanthi Kumari Nunna} \\ Dept of Electronics Engineering, University of Petroleum and Energy Studies, Dehradun- \\ 248007, Uttarakhand-India \\ * indicates corresponding Author
}

\begin{abstract}
The results of the experiments showed that bed weight, flow rate, and initial metal ion concentration all play a role in the removal of $\mathrm{Cr}$ (III) and $\mathrm{Fe}$ (II). The optimized break through curve was obtained at $36 \mathrm{~cm}$ bed height and 10ml/min for chromium where 97.5 to $100 \%$ removal was observed at a saturation time of 500-600 min. With the increase in bed height from $12 \mathrm{~cm}$ to $36 \mathrm{~cm}$, both the breakthrough and saturation times for Cr (III) increased. The break through time at $12 \mathrm{~cm}, 24 \mathrm{~cm}, 36 \mathrm{~cm}$ and $10 \mathrm{ml} / \mathrm{min}$ for $\mathrm{Cr}$ (III) were $70 \mathrm{~min}, 105 \mathrm{~min}$, and 35 min respectively. The saturation time for $\mathrm{Cr}(I I I)$ at $12 \mathrm{~cm}, 24 \mathrm{~cm}, 36 \mathrm{~cm}$ and $10 \mathrm{ml} / \mathrm{min}$ were $460 \mathrm{~min}, 490 \mathrm{~min}$, and $500 \mathrm{~min}$ respectively. Similarly, the break through time for Fe (II) at $12 \mathrm{~cm}, 24 \mathrm{~cm}, 36 \mathrm{~cm}$ and $10 \mathrm{ml} / \mathrm{min}$ were $70 \mathrm{~min}, 80 \mathrm{~min}$, and $100 \mathrm{~min}$ respectively. At $12 \mathrm{~cm}$, $24 \mathrm{~cm}, 36 \mathrm{~cm}$, and $10 \mathrm{ml} / \mathrm{min}$, the saturation time for $\mathrm{Fe}$ (III) was 340 minutes, 360 minutes, and 430 minutes, respectively. Overall in the column performance comparison between synthetic solution and industrial effluents for chromium, synthetic solution performance was more superior at fixed volumetric flow rates of $10 \mathrm{ml} / \mathrm{min}$ and bed heights ranging from $12 \mathrm{~cm}$ to 36 $\mathrm{cm}$ But the reverse trend was observed in case of fixed bed heights of $36 \mathrm{~cm}(150 \mathrm{~g})$ and variation of volumetric flow rates from $10 \mathrm{ml} / \mathrm{min}$ to $30 \mathrm{ml} / \mathrm{min}$ which indicates that industrial effluent performance was superior when compared to synthetic solution for heavy metal removal.
\end{abstract}

Key words: Bed weight, Volumetric Flow rate, Initial Metal ion Concentration, Break through curve, Saturation time, Break through time, Synthetic solution, Industrial effluents 


\section{Introduction}

Heavy metal ion contamination of surface waters has become a serious ecological and health issue due to their toxic effect even at low concentrations. Heavy metals are a particular source of concern because

They are non-biodegradable and thus long-lasting. Heavy metal ions such as cobalt, copper, chromium, nickel, palladium, lead, and zinc have been found in mining waste streams [1], tanneries [2], electronics [3], electroplating, batteries [4] and petrochemicals [5] industries has major effects on the human and aquatic life [6].

Water pollution is still a major issue in the environment as a result of urbanization and industrialization which have contributed to the large scale of pollution for both human and aquatic life. The wastewater is discharged into the streams. Wells, Rivers and other water bodies without proper treatment. The pollution depreciates the land values, increases the municipal cost, operational cost and cause adverse biological and human health effects. Heavy metals are non-biodegradable in nature, and their presence in water streams causes bioaccumulation in living organisms, resulting in animal health problems, plants and human life damage [7]. Industrial effluents containing enormous quantities of inorganic and organic chemical wastes, which are steadily become more difficult to treat by ongoing conventional methods.

For the treatment of organic-contaminated wastewater, conventional treatment technologies such as chemical precipitation, ion exchange, electrodialysis, membrane separations, reverse osmosis, and solvent extraction and adsorption have been considered. Adsorption was discovered to be the most effective method among them [8]. Adsorption has been found to be superior to all other treatment methods due to its simplicity of design, ease of operation, and ability to efficiently adsorb a wide range of different types of adsorbate concentrations. Commercial activated carbon is widely regarded as the most effective material for reducing organic load [5].

Adsorption denotes to the separation of solute particles in a confined space from a liquid phase (fluid phase) on to solid surface. The adsorbate particle travels from the fluid segment to the boundary, where it remains for a phase interval. In a rescindable method, particles return to the segment from which they came or reversibly cross into another segment while other particles exchange them at the boundary. On accomplishment of the solid surface, the adsorbed particles interchange energy with structural atoms of the outside surface and if enough period was once there for adsorption, the adsorbed particles and the surface atoms reach thermal stability. The quantity of molecules entering on the boundary in a assumed period is equivalent to the number of molecules parting the boundary to go into the fluid segment [9-10].

\subsection{Break through Curves}

The breakthrough curve concept was used to describe the performance of a fixed-bed column. The time for breakthrough appearance and the shape of the breakthrough curves are critical 
characteristics for determining an adsorption column's operation and dynamic response. In most cases, the loading behaviour of a metal ion to be adsorbed from solution in a fixed-bed is expressed in terms. $\mathrm{C}_{\mathrm{e}} / \mathrm{C}_{\mathrm{o}}$ as a function of time or effluent volume for a given bed weight, yielding a breakthrough curve

In any case, the efficiency of an adsorption treatment is primarily determined by the thermodynamic aspects of solute-solvent-sorbent interactions as well as transport phenomena involving diffusive-convective transport within porous media $[11,12]$.

In a fixed-bed device, contaminated water is introduced from the top of the column into a clean bed of mixed adsorbent, and pollutant removal occurs in a narrow band at the top of the column known as the mass transfer / exchange zone (MTZ). As the operation progresses, the upper layers of blended adsorbent become saturated (soaked) with solute, and the adsorption zone moves downward until it reaches the bottom of the column. Under these conditions, the concentration of solutes in the effluent begins to rise. The extent of the MTZ is primarily determined by the liquid-solid relative velocity and the adsorbent properties (particle diameter, micro porous structure).

The greater the MTZ extent, the less efficient the use of the adsorbing bed. Experiment results showed that increasing the initial concentration and the liquid flow rate results in a shorter breakpoint time; additionally, the breakthrough curves become steeper as a result of higher velocity, which improves external mass transport. Break through curves are plots that show a relationship between $\ln (\mathrm{Ce} / \mathrm{Co})$ vs reaction time in terms of various linear models (with different parameters) and predict the nature of the adsorbent-adsorbate system. They are affected by the volumetric flow rate, the weight of the adsorbent packed at various bed weights, and the initial metal ion concentration of the metal ion solution. The concentration ratio profile is obtained by studying the variation of flow rate with bed weight at a fixed initial concentration of $100 \mathrm{ppm}$ gives the concentration ratio profile with respect to outlet effluent sampling time (min).

In this paper a systematic and detailed study have been carried out to for the removal of Fe (II) and $\mathrm{Cr}$ (III) using mixed adsorbent prepared by mixing activated charcoal and bone Charcoal in continuous flow studies, (1:1 ratio) is used, and the results are presented in the form of a break through curve.

\section{Materials \& Methods}

All the chemicals including adsorbents used for the studies were purchased from Sigma Aldrich, India and have purity above $99.5 \%$. All reagents and buffer solutions used in the study were of Analytical grade.

\subsection{Methods}

Absorption of Atoms A spectrophotometer (Thermo Scientific ICE 3000 series) was used to examine $\mathrm{Cr}$ (III) and Fe (II) before and after adsorption. 


\subsubsection{Preparation of the mixed adsorbent}

The mixed adsorbent was prepared in 1:1 ratio and sieve analysis (SELEC XT 264, AIMIL company ltd) was carried out in a rotary sieve shaker to determine the particle size of the mixed adsorbent. The mixed adsorbent's average particle diameter was determined to be $572.2 \mathrm{~nm}$ (Nano meters).

\subsubsection{Column Studies}

Experiments with continuous flow operation were carried out in a transparent cylindrical plastic column ( $4 \mathrm{~cm}$ internal diameter and $100 \mathrm{~cm}$ height). A stainless sieve with a mesh size of 20 was attached to the bottom of the column. To achieve the desired bed height, a known quantity of the adsorbent in the ratio of 1:1 (mixed adsorbent) was added to the column $(12 \mathrm{~cm}$, $24 \mathrm{~cm}, 36 \mathrm{~cm})$. Cr (III) and Fe (II) solution of known concentration (100 mg/l was pumped into the column using a $40 \mathrm{~W}$ submersible pump at the desired flow rate $(10 \mathrm{ml} / \mathrm{min}, 20 \mathrm{ml} / \mathrm{min}$, $30 \mathrm{ml} / \mathrm{min}$ ). Samples were collected from the column's exit at various bed heights and time intervals until equilibrium was reached and analyzed using an Atomic Absorption Spectrophotometer (AAS). The diagram below depicts the experimental setup of the Packed bed column, as shown in Figure 1. The experimental setup consists of two parts: (1) a reservoir tank and (2) a peristaltic pump to transport the water from Reservoir tank (3) Packed bed filled with $50 \%$ each mixture of Activated Charcoal and Bone charcoal

\subsection{Parameters \& Dimensions of the packed bed column}

Weight of mixed adsorbent added 50g, 100g, and $150 \mathrm{~g}$ (for $12 \mathrm{~cm}-25 \mathrm{~g}$ each; for $24 \mathrm{~cm}-50 \mathrm{~g}$ each; for $36 \mathrm{~cm}-75 \mathrm{~g}$ each.)

Inner Diameter of the column: $4 \mathrm{~cm}$

Bed height studied $=12,24,36 \mathrm{~cm}$

Total height of the column $=100 \mathrm{~cm}$

Adsorbent ratio $=1: 1(\mathrm{AC}+\mathrm{BC})$

Submersible pump used to send the effluent into the column consumes 40 Watts.

Initial Metal Con of the metal ions $\mathrm{Cr}$ and $\mathrm{Fe}\left(\mathrm{C}_{\mathrm{o}}\right)=100 \mathrm{ppm}$

Volumetric flow rates of $-10,20$, and $30 \mathrm{ml} / \mathrm{min}$ have an effect.

Effect of adsorbent weight (bed height) $-12 \mathrm{~cm}, 24 \mathrm{~cm}, 36 \mathrm{~cm}$

\subsection{The investigation of bed heights (adsorbent weight) and volumetric flow rate}

The packed bed column design was investigated at bed heights of $12 \mathrm{~cm}, 24 \mathrm{~cm}$, and $36 \mathrm{~cm}$, as well as flow rates ranging from 10,20, and $30 \mathrm{ml} / \mathrm{min}$ with an initial concentration of $100 \mathrm{ppm}$. The main design of the column involves the study of break through curves experimentally with the effect of bed height and volumetric flow rate. 

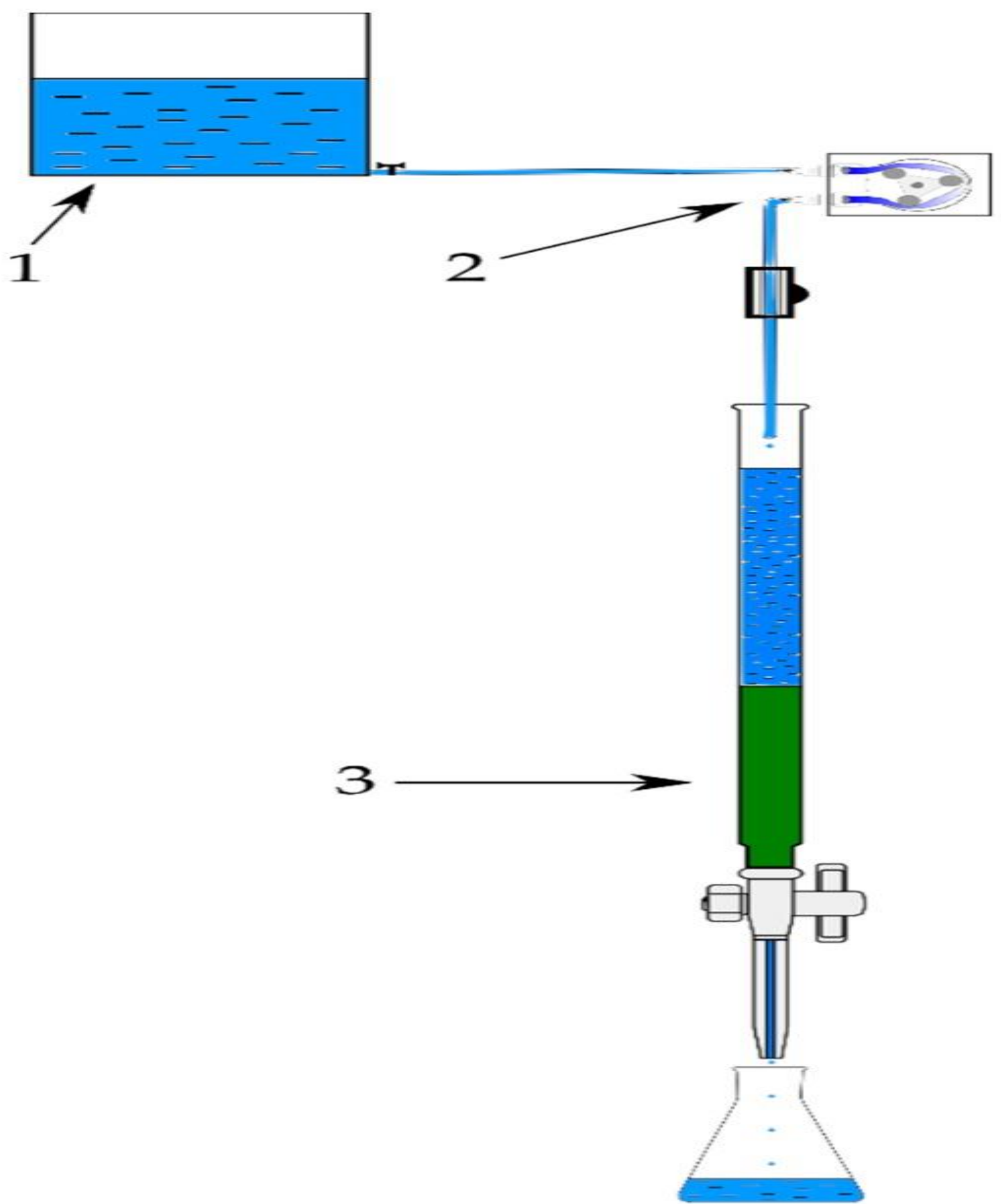

Fig 1 Laboratory Experimental setup of Continuous flow column

\section{Results \& Discussion}

Continuous column study experiments were conducted for both chromium and Iron in packed bed column for the parameters such as effect of bed height $(12,24,36 \mathrm{~cm})$ at fixed volumetric flow rate of $10 \mathrm{ml} / \mathrm{min}$, and effect of volumetric flow rate $(10,20,30 \mathrm{ml} / \mathrm{min})$ at fixed bed height of $36 \mathrm{~cm}$ are carried out and the results were compared with the synthetic solution data in terms of \% removal, breakthrough time and saturation time. 


\subsection{Effect of bed height and adsorbent dosage on the removal of $\mathrm{Cr}$ (III) and $\mathrm{Fe}$ (II) from industrial effluent}

The adsorption of metal ions in the packed bed column was found to be directly proportional to the amount of adsorbent in the column. The blended adsorbent (1:1 ratio) of $50 \mathrm{~g}, 100 \mathrm{~g}$, and $150 \mathrm{~g}$ are taken in the column and experiments were carried out in order to investigate the parameters and assess the efficiency of the column in the adsorption process. The adsorption breakthrough curves are obtained by varying the bed height between 12, 24, and $36 \mathrm{~cm}$ while maintaining a constant volumetric flow rate of $10 \mathrm{ml} / \mathrm{min}$. A bed height of $12 \mathrm{~cm}$ resulted in faster breakthrough curves, while a bed height of $36 \mathrm{~cm}$ resulted in the slowest breakthrough curve. Higher the absorbent packed in the column, more the active sites that are accessible for the metal particles to attach and diffuse deep on to the pores as well as on to the surface of the mixed adsorbent [13] which leads to the achievement of higher bed capacity. Further, when the flow rate is less, the metal ion solution has more contact time to run in the column and the increment of bed height brought more active sites that were being in contact with the metal ions to interact and bind with the adsorbent [14]. This phenomenon has permitted the metal particles to diffuse deeper into the active sites of the mixed adsorbent. As a result, increasing the bed height increased the percentage of metal ion removal. The breakthrough and saturation times for $\mathrm{Cr}$ (III) increased as the bed height increased from $12 \mathrm{~cm}$ to $36 \mathrm{~cm}$. The break through time at 12, 24, $36 \mathrm{~cm}$ and $10 \mathrm{ml} / \mathrm{min}$ for $\mathrm{Cr}$ (II) were 70, 105, and $35 \mathrm{~min}$ respectively. The saturation time for $\mathrm{Cr}$ (II) at 12, 24, 36 cm and $10 \mathrm{ml} / \mathrm{min}$ were 460, 490, and $500 \mathrm{~min}$ respectively. It can be observed from Figs. 2 and 3 that the optimized break through curve were obtained at $36 \mathrm{~cm}$ bed height and $10 \mathrm{ml} / \mathrm{min}$ and further predicts that $36 \mathrm{~cm}$ bed height was chosen as the optimal value, and subsequent experiments were carried out at $20 \mathrm{ml} / \mathrm{min}$, $30 \mathrm{ml} / \mathrm{min}$, and $36 \mathrm{~cm}$ bed height to investigate the effect of volumetric flow rate on $\mathrm{Cr}$ (III) and Fe (II) metal ion removal using packed bed column. Similarly, the break through time for Fe (II) at $12,24,36 \mathrm{~cm}$ and $10 \mathrm{ml} / \mathrm{min}$ were 70,80 , and $100 \mathrm{~min}$ respectively. The saturation time for Fe (II) at 12, 24, $36 \mathrm{~cm}$ and $10 \mathrm{ml} / \mathrm{min}$ were 340, 360, and $430 \mathrm{~min}$, respectively.

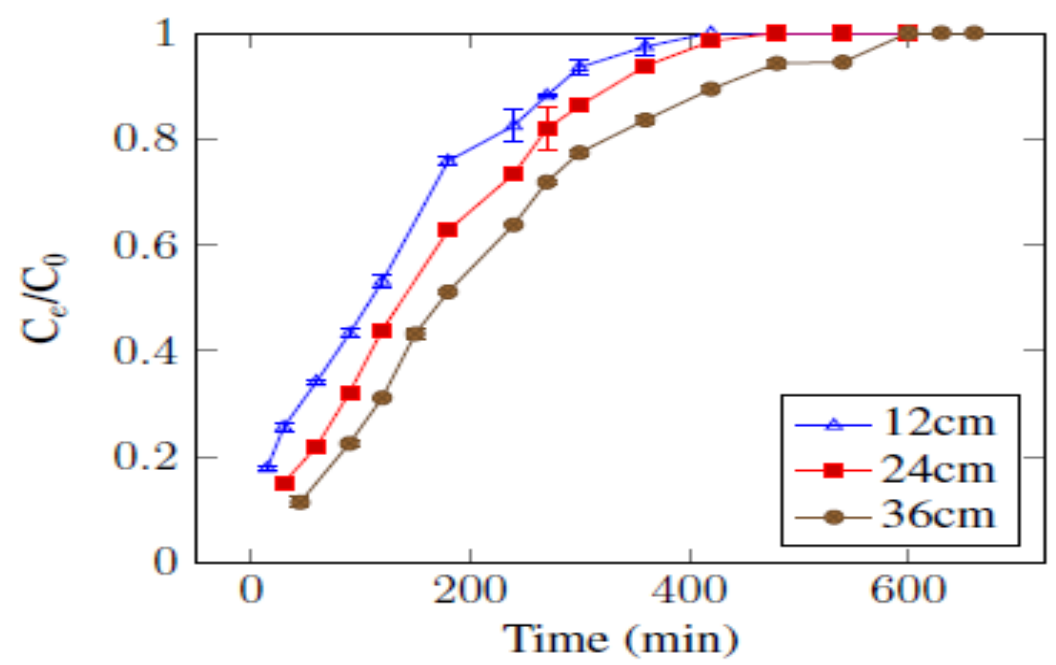

Fig 2 Breakthrough curves for chromium at $10 \mathrm{ml} / \mathrm{min}$ flow rate, IMC of $100 \mathrm{ppm}$ at different bed heights of 12, 24 and $36 \mathrm{~cm}$ 


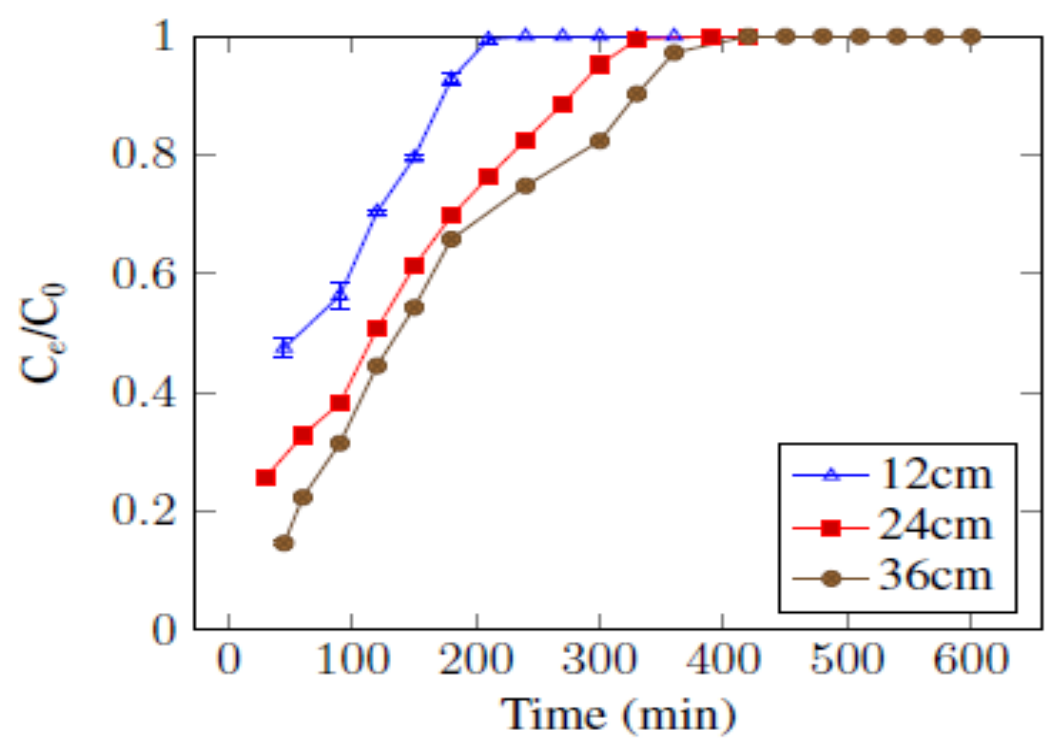

Fig 3 Breakthrough curves for iron at $10 \mathrm{ml} / \mathrm{min}$ flow rate, IMC of $100 \mathrm{ppm}$ at different bed heights of 12, 24 and $36 \mathrm{~cm}$

\subsection{Effect of volumetric flow rate on $\mathrm{Cr}$ (III) and $\mathrm{Fe}$ (II) removal from industrial effluent} The effect of flow rate on $\mathrm{Cr}$ (II) and Fe (II) ions from industrial effluent using the mixed adsorbent was investigated by varying the flow rate of the metal ion solution from 10, 20, and $30 \mathrm{ml} / \mathrm{min}$ while maintaining the fixed initial metal ion concentration of $100 \mathrm{mg} / \mathrm{l}$ and bed height at $36 \mathrm{~cm}(150 \mathrm{~g})$. At different flow rates, a graph of metal ion concentration ratio on yaxis vs effluent outlet time / sampling time on x-axis was plotted. Due to less contact time between the metal ion particle and the mixed adsorbed, the highest flow rate of $30 \mathrm{ml} / \mathrm{min}$ with a bed height of $36 \mathrm{~cm}$ resulted in a faster breakthrough.

When the volumetric flow rate increased, there was less contact time between the metal ion and the adsorbent, resulting in a decrease in bed capacity. However, at lower flow rates of metal ion solution, the contact time between the metal ions and the adsorbent was longer [14], resulting in a slower breakthrough curve. At higher flow rates, the metal ion solution will leave the bed before reaching equilibrium. As a result, less metal ion concentration will be adsorbed from industrial effluent.

The break through time and saturation time for $\mathrm{Cr}$ (III) at $36 \mathrm{~cm}(150 \mathrm{~g})$ with different flow rates of 10,20, 30 were 35 and $500 \mathrm{~min} ; 20$ and $360 \mathrm{~min} ; 10$ and $230 \mathrm{~min}$, respectively were observed in this experimental study. Similarly, the break through time and saturation time for Fe (III) at $36 \mathrm{~cm}(150 \mathrm{~g})$ with different flow rates of 10, 20, $30 \mathrm{ml} / \mathrm{min}$ were 100 and $430 \mathrm{~min}$; 80 and $280 \mathrm{~min} ; 50$ and $250 \mathrm{~min}$, respectively were observed. In the continuous column experiments, the breakthrough point shifted towards the right side for both $\mathrm{Cr}$ (III) and $\mathrm{Fe}$ (II) (II) when the adsorbent dosage was increased from 50 to $150 \mathrm{~g}$ with a constant initial metal ion concentration of 100 ppm. It was observed from the Fig $\mathbf{4}$ and Fig $\mathbf{5}$ that the optimized breaks through curves were obtained at $36 \mathrm{~cm}$ and $10 \mathrm{ml} / \mathrm{min}$ for both $\mathrm{Cr}$ (III) and $\mathrm{Fe}$ (II). A longer 
breakthrough time implies better adsorption capacity which means that it would take a longer time for the adsorbent material to completely get saturated with the adsorbate solution.

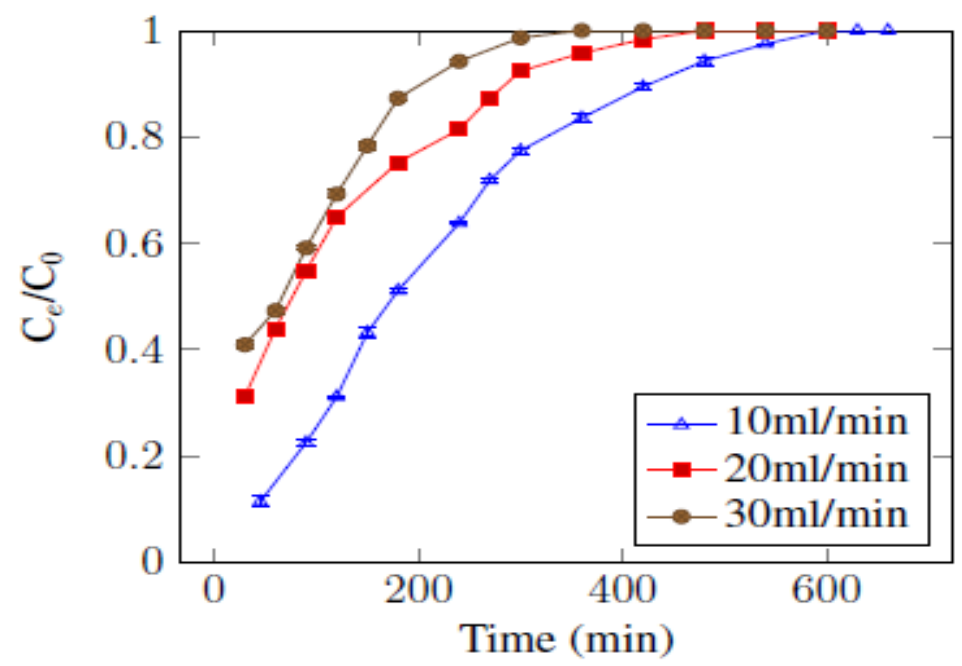

Fig 4: Chromium breakthrough curves at $36 \mathrm{~cm} \mathrm{BH,} \mathrm{IMC} \mathrm{of} 100 \mathrm{ppm}$, and flow rates of $10 \mathrm{ml} / \mathrm{min}, 20 \mathrm{ml} / \mathrm{min}$, and $30 \mathrm{ml} / \mathrm{min}$.

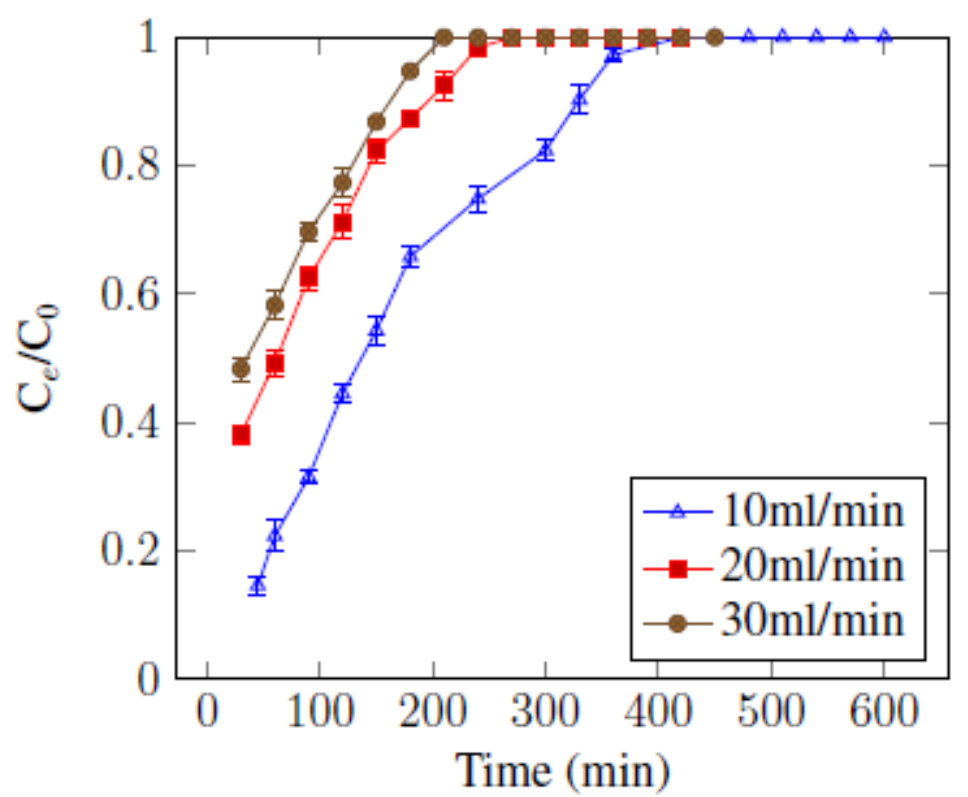

Fig 5: Breakthrough curves of iron at $36 \mathrm{~cm} \mathrm{BH,} \mathrm{IMC} \mathrm{of} 100 \mathrm{ppm}$ at different flow rates of $10 \mathrm{ml} / \mathrm{min}, 20 \mathrm{ml} / \mathrm{min}$, and $30 \mathrm{ml} / \mathrm{min}$

\subsection{Comparative studies for industrial effluent and synthetic sample in continuous flow study}

The results obtained through column studies using industrial and synthetic solutions for copper and cadmium were compared in terms of breakthrough time, saturation time and \% removal of metal ions. There was a small significant time difference of break through time $(70,90,100$ $\min$ ) for synthetic solutions at fixed volumetric flow rates and variation of bed height in comparison with industrial sample having $(70,105,35 \mathrm{~min})$ for chromium. This large time 
difference in industrial effluent was due to the presence of other heavy metal ions like phenol, cresol, heavy metal pollutants other sludge in the industrial effluent so that it has taken more time to reach break through points.

Similarly, the same trend for chromium was observed for saturation time (more time taken in case of industrial effluent) in comparison with synthetic solution and this may be due to the presence of other heavy metals which blocks the adsorbent pores and in turn leads to more saturation time. But in case of different volumetric flow rates and fixed bed heights of $(36 \mathrm{~cm}$ or $150 \mathrm{~g}$ dosage) a huge time difference of $270 \mathrm{~min}$ for industrial effluents , $275 \mathrm{~min}$ for synthetic effluents) was observed for saturation time as shown in Table 1 and Table 2. respectively.

This was due to the increase in dosage from $50 \mathrm{~g}$ to $150 \mathrm{~g}$ in the column, as there was a greater number of active sites present in the column that are readily available for metal ions to occupy and further leads to saturation delay. But in case of breakthrough time at fixed bed height of $36 \mathrm{~cm}$ and varying volumetric flow rates there was a difference of $65 \mathrm{~min}, 60 \mathrm{~min}, 60 \mathrm{~min}$ were observed at 10,20,30 $\mathrm{ml} / \mathrm{min}$ respectively between the industrial and synthetic solutions for chromium removal.

This was due to the increase in volumetric flow rate from 10 to $30 \mathrm{ml} / \mathrm{min}$. More metal ion solution was passed through the column as the flow rate increased, and there was a competitive adsorption of metals ions for the same active sites, and due to the presence of other heavy metals, the pores became blocked quickly, resulting in a difference in breakthrough time and break through achieved late for synthetic solutions.

In comparison with column performance in terms of total \% removal at 12 and $24 \mathrm{~cm}$ and a fixed vol. flow rate of $10 \mathrm{ml} / \mathrm{min}$, the more $\%$ removal was observed in case of synthetic samples having $61.02 \%, 68.47 \%$ than industrial effluents. The less $\%$ removal was observed for synthetic sample $(96.20 \%)$ at $36 \mathrm{~cm}$ bed height $(150 \mathrm{~g})$ and $10 \mathrm{ml} / \mathrm{min}$ when compared to industrial sample having $98.8 \%$ as shown in Table 1 and Table 2. This difference of $2.6 \%$ removal between the industrial effluent and synthetic sample for copper was due to more adsorbent dosage of $150 \mathrm{~g}$ at $36 \mathrm{~cm}$ bed height. Similarly, at fixed bed height of $36 \mathrm{~cm}(150 \mathrm{~g})$ and varying volumetric flow rates from $10,20,30 \mathrm{ml} / \mathrm{min}$ there were a difference of $2.6 \%$, $15.28 \%$, and $16.93 \%$ between industrial effluent and synthetic samples for chromium was observed and this may be due to more dosage of $150 \mathrm{~g}$ at $36 \mathrm{~cm}$ bed height. Overall in the column performance comparison between synthetic samples and industrial effluents for chromium, synthetic solution performance was more superior at fixed volumetric flow rates of $10 \mathrm{ml} / \mathrm{min}$ and bed heights ranging from 12 to $36 \mathrm{~cm}$.

However, a reverse trend was observed for chromium in case of fixed bed heights of $36 \mathrm{~cm}$ $(150 \mathrm{~g})$ and variation of volumetric flow rates from $10 \mathrm{ml} / \mathrm{min}$ to $30 \mathrm{ml} / \mathrm{min}$ which indicates that industrial effluent performance was superior as compared to synthetic solution and this may be due to the more adsorbent dosage and influence of synergistic effect in the column. Tables 1 and 2 show the data for industrial effluent and synthetic chromium solution, 
respectively. Similarly, for iron there was a significant time difference of breakthrough time $(60,25,50 \mathrm{~min})$ for synthetic solutions and industrial effluent having (70 min, $80 \mathrm{~min}, 100$ min) at fixed volumetric flow rates and variation of bed height for iron was observed.

The breakthrough time increases for iron -industrial effluent due to the presence of other heavy metals, phenols, cresols, and other sludge that affects the performance of the packed bed column and also gives competitive adsorption effect for iron along with other metals present in the industrial effluent which was sent in the column.

Similarly the same trend was observed for iron in-terms of saturation time in comparison with the synthetic solution and this may be due to presence of other heavy metals that blocks the adsorbent pores and in turn leads to more saturation time at fixed volumetric flow rate of 10 $\mathrm{ml} / \mathrm{min}$ and different bed heights of 12 and $24 \mathrm{~cm}$. But at $36 \mathrm{~cm}$ and $10 \mathrm{ml} / \mathrm{min}$, for the iron removal, the saturation time for industrial effluent decreased (430 $\mathrm{min}$ ) in comparison with synthetic sample having (460 min) and this may be due to an increase in bed height, which results in increased adsorption capacity (due to adsorbent dose) in the column, as well as due to the presence of synergistic effect of the mixed adsorbent which leads to quick saturation time for industrial effluent.

In case of fixed bed height of $36 \mathrm{~cm}(150 \mathrm{~g})$ and different volumetric flow rates from 10 to 30 $\mathrm{ml} / \mathrm{min}$, the break through time increased from 50 to $100 \mathrm{~min}$ at $10 \mathrm{ml} / \mathrm{min}, 30$ to $80 \mathrm{~min}$ at 20 $\mathrm{ml} / \mathrm{min}$, and the break through time increased from 10 to $50 \mathrm{~min}$ at $30 \mathrm{ml} / \mathrm{min}$ as shown in Tables 3 and 4. This increase in break through time for industrial effluent was due to the presence of other heavy metals and sludge that plays a role of competitive adsorption in the column along with iron [15-17].

Similar to chromium, a reverse trend for iron was observed in-terms of saturation time at fixed bed height of $36 \mathrm{~cm}$ and different volumetric flow rates. [18-19]. The saturation time was more for synthetic samples (460, $340 \mathrm{~min}$ ) when compared to industrial effluents (430, $280 \mathrm{~min}$ ) and this may be due to the presence of synergistic effect of the mixed adsorbent as well as high amount of dose (150 g) in the column [20-21].

The reverse trend for iron was observed at $30 \mathrm{ml} / \mathrm{min}$ and $150 \mathrm{~g}$, where the saturation time was less in case of synthetic sample (220 min) when compared to industrial effluent having (250 $\mathrm{min}$ ) and this may be due to more volumetric flow rate of $(30 \mathrm{ml} / \mathrm{min})$ as well as due to the presence of other heavy metals that blocks the adsorbent particles and further leads to the late arrival of saturation zone as shown in the Tables 3 and 4.

In comparison with the column performance of iron in terms of total \% removal, at 12, 24, 36 $\mathrm{cm}$ and $10 \mathrm{ml} / \mathrm{min}$ (fixed volumetric flow rate), the more \% removal was observed in case of synthetic samples having 35.7\%, 70.03\%, $73.63 \%$ in comparison with industrial sample having $29 \%, 55.69 \%, 52.86 \%$, respectively. 
The different type of trend for chromium was observed at fixed bed height of $36 \mathrm{~cm}(150 \mathrm{~g})$ and different volumetric flow rates of 10,20 , and $30 \mathrm{ml} / \mathrm{min}$ [22-23].The more \% removal was observed for industrial samples having $96.2 \%, 72.63 \%$, and $81.77 \%$ in comparison with synthetic effluents having $98.8 \%, 87.91 \%$, and $98.71 \%$ which was due to the presence of other heavy metals, sludges apart from competitive adsorption of chromium present in the industrial effluent [24-25].Overall in comparison with industrial effluents for iron, the synthetic solutions have proved to be more superior in terms of total \% removal and better performance was observed with synthetic solutions rather than industrial effluents for iron as shown in Tables 3 and 4 respectively. For a similar comparison studies with chromium, the industrial effluents proved to be more percentage removal as compared to synthetic solutions[23-25].

Table 1: Column performance calculations of industrial effluent for chromium removal at different bed heights and volumetric flow rates

\begin{tabular}{|c|c|c|c|c|c|c|c|c|c|c|}
\hline $\begin{array}{c}\text { Ads } \\
\text { dosage } \\
(\mathrm{g})\end{array}$ & $\begin{array}{c}\text { Bed } \\
\text { height } \\
(\mathrm{cm})\end{array}$ & $\begin{array}{c}\text { Vol. } \\
\text { flow } \\
\text { rates } \\
(\mathrm{ml} / \mathrm{min})\end{array}$ & $\mathrm{IMC}$ & $\begin{array}{c}\text { Break } \\
\text { through } \\
\text { time } \\
(\mathrm{min})\end{array}$ & $\begin{array}{c}\text { saturation } \\
\text { time }( \\
\mathrm{min})\end{array}$ & $\begin{array}{c}\text { Vol treated } \\
\text { at } \\
\text { breakthrough } \\
\text { point }(\mathrm{ml})\end{array}$ & $\begin{array}{c}\text { Vol } \\
\text { treated at } \\
\text { saturation } \\
\text { point } \\
(\mathrm{ml})\end{array}$ & $\mathrm{M}_{\mathrm{ad}}(\mathrm{g})$ & $\mathrm{m}_{\text {total }}(\mathrm{g})$ & $\begin{array}{c}\text { Total \% } \\
\text { removal }\end{array}$ \\
\hline 50 & 12 & 10 & 100 & 70 & 460 & 550 & 4600 & 271 & 460 & 58.9 \\
\hline 100 & 24 & 10 & 100 & 105 & 490 & 1000 & 4900 & 284 & 490 & 57.96 \\
\hline 150 & 36 & 10 & 100 & 35 & 500 & 480 & 5000 & 494 & 500 & 98.8 \\
\hline 150 & 36 & 20 & 100 & 20 & 360 & 640 & 7200 & 633 & 720 & 87.91 \\
\hline 150 & 36 & 30 & 100 & 10 & 230 & 480 & 6900 & 681 & 690 & 98.7 \\
\hline
\end{tabular}

Table 2: Column performance calculations of synthetic solution (chromium) removal at different bed heights and volumetric flow rates

\begin{tabular}{|c|c|c|c|c|c|c|c|c|c|c|}
\hline $\begin{array}{c}\text { Ads } \\
\text { dosage } \\
(\mathrm{g})\end{array}$ & $\begin{array}{c}\text { Bed } \\
\text { height } \\
(\mathrm{cm})\end{array}$ & $\begin{array}{c}\text { Volumetric } \\
\text { flow rates } \\
(\mathrm{ml} / \mathrm{min})\end{array}$ & $\mathrm{IMC}$ & $\begin{array}{c}\text { Break } \\
\text { through } \\
\text { time } \\
(\mathrm{min})\end{array}$ & $\begin{array}{c}\text { saturation } \\
\text { time( } \\
\mathrm{min})\end{array}$ & $\begin{array}{c}\text { Vol treated } \\
\text { at } \\
\text { breakthrough } \\
\text { point }(\mathrm{ml})\end{array}$ & $\begin{array}{c}\text { Vol } \\
\text { treated at } \\
\text { saturation } \\
\text { point } \\
(\mathrm{ml})\end{array}$ & $\mathrm{M}_{\mathrm{ad}}$ & $\mathrm{m}_{\text {total }}(\mathrm{g})$ & $\begin{array}{c}\text { Total \% } \\
\text { removal }\end{array}$ \\
\hline 50 & 12 & 10 & 100 & 70 & 440 & 550 & 4400 & 268.5 & 440 & 61.02 \\
\hline 100 & 24 & 10 & 90 & 60 & 460 & 750 & 4600 & 315 & 460 & 68.47 \\
\hline 150 & 36 & 10 & 100 & 65 & 500 & 680 & 5000 & 481 & 500 & 96.2 \\
\hline 150 & 36 & 20 & 80 & 55 & 380 & 850 & 7600 & 552 & 760 & 72.63 \\
\hline 150 & 36 & 30 & 70 & 50 & 225 & 1000 & 6750 & 604 & 675 & 81.77 \\
\hline
\end{tabular}


Table 3: Column performance calculations of industrial effluent for iron removal at different bed heights and volumetric flow rates

\begin{tabular}{|c|c|c|c|c|c|c|c|c|c|c|}
\hline $\begin{array}{l}\text { Ads } \\
\text { dosage } \\
(\mathrm{g})\end{array}$ & $\begin{array}{c}\text { Bed } \\
\text { heights } \\
(\mathrm{Cm})\end{array}$ & $\begin{array}{c}\text { Volumetric } \\
\text { flow rates } \\
(\mathrm{ml} / \mathrm{min})\end{array}$ & IMC & $\begin{array}{c}\text { Break } \\
\text { through } \\
\text { time } \\
(\mathrm{min})\end{array}$ & $\begin{array}{c}\text { saturation } \\
\text { time( } \\
\text { min) }\end{array}$ & $\begin{array}{l}\text { Vol treated } \\
\text { at } \\
\text { breakthrough } \\
\text { point (ml) }\end{array}$ & $\begin{array}{c}\text { Vol } \\
\text { treated at } \\
\text { saturation } \\
\text { point } \\
\text { (ml) }\end{array}$ & $\mathrm{M}_{\mathrm{ad}}$ & $\mathrm{m}_{\text {total }}(\mathrm{g})$ & $\begin{array}{l}\text { Total \% } \\
\text { removal }\end{array}$ \\
\hline 50 & 12 & 10 & 100 & 70 & 340 & 530 & 3400 & 98.6 & 340 & 29 \\
\hline 100 & 24 & 10 & 100 & 80 & 360 & 620 & 3600 & 200.5 & 360 & 55.69 \\
\hline 150 & 36 & 10 & 100 & 100 & 430 & 940 & 4300 & 227.3 & 430 & 52.86 \\
\hline 150 & 36 & 20 & 100 & 80 & 280 & 1250 & 5600 & 215 & 560 & 38.39 \\
\hline 150 & 36 & 30 & 100 & 50 & 250 & 950 & 5000 & 322.5 & 500 & 64.5 \\
\hline
\end{tabular}

Table 4: Column performance calculations of synthetic solutions for iron removal at different bed heights and volumetric flow rates

\begin{tabular}{|c|c|c|c|c|c|c|c|c|c|c|}
\hline $\begin{array}{c}\text { Ads } \\
\text { dosage } \\
\text { (g) }\end{array}$ & $\begin{array}{l}\text { Bed } \\
\text { height } \\
(\mathrm{cm})\end{array}$ & $\begin{array}{l}\text { Volumetric } \\
\text { flow rates } \\
(\mathrm{ml} / \mathrm{min})\end{array}$ & IMC & $\begin{array}{c}\text { Break } \\
\text { through } \\
\text { time } \\
(\min )\end{array}$ & $\begin{array}{l}\text { Saturation } \\
\text { time (min) }\end{array}$ & $\begin{array}{l}\text { Vol treated } \\
\text { at } \\
\text { breakthrough } \\
\text { point }(\mathrm{ml})\end{array}$ & $\begin{array}{c}\text { Vol of } \\
\text { sol } \\
\text { treated at } \\
\text { saturation } \\
\text { point } \\
(\mathrm{ml})\end{array}$ & $\mathrm{M}_{\mathrm{ad}}$ & $\begin{array}{c}\mathrm{m}_{\text {total }} \\
(\mathrm{g})\end{array}$ & $\begin{array}{l}\text { Total \% } \\
\text { removal }\end{array}$ \\
\hline 50 & 12 & 10 & 100 & 60 & 200 & 520 & 2000 & 71.4 & 200 & 35.7 \\
\hline 100 & 24 & 10 & 100 & 25 & 335 & 330 & 3350 & 234.6 & 335 & 70.03 \\
\hline 150 & 36 & 10 & 100 & 50 & 460 & 620 & 4600 & 338.7 & 460 & 73.63 \\
\hline 150 & 36 & 20 & 100 & 30 & 340 & 870 & 6800 & 396.2 & 680 & 58.26 \\
\hline 150 & 36 & 30 & 100 & 10 & 220 & 950 & 4400 & 293.8 & 440 & 66.77 \\
\hline
\end{tabular}

\section{Conclusions}

Based on the analysis of data obtained in continuous flow operation from breakthrough curves and kinetic models. It was concluded that the mixed adsorbent is the better adsorbent for heavy metal ion removal. The experimental results demonstrated that bed weight, flowrate, and initial metal ion concentration all have a significant impact on the removal of $\mathrm{Cr}$ (III) and $\mathrm{Fe}$ (II).

Overall in comparison with industrial effluents for iron, the synthetic solutions have proved to be more superior in terms of column performance, total \% removal and better performance was observed with synthetic solutions than industrial effluents in case of iron and a reverse trend was observed for chromium with high \% removal for industrial effluents. In continuous column studies, a longer breakthrough time indicates greater adsorption capacity, implying that the adsorbent 
material will take longer to become completely saturated with the adsorbate solution. The adsorbent can be used for a longer period of time before it needs to be replaced or regenerated.

\section{REFERENCES}

[1] N Ahalya;TV Ramachandra; RD Kanamadi. Biosorption of Heavy Metals Research Journal of Chemistry and Environment; 2003,7(4), 71-79.

[2] G Aman;I Tehseen. Potato Peels as Solid Waste for Heavy Metal Copper (II) Removal from Waste Water/Industrial Effluent. Colloids and Surfaces B: Biointerfaces; 2003,63 (1), 116-121.

[3] Jiang Yu, Hao Pang, and Bing Liao.Removal of Copper (II) Ions from Aqueous Solution by Modified Bagasse.Journal of Hazardous Materials; 2009,164 (1),1-9.

[4] W Shaobin ; HM Ang; MO Tade. Novel Applications of Red Mud as Coagulant, Adsorbent and Catalyst for Environmentally Benign Processes.Chemosphere; 2008,72 (11), 1621-1635.

[5] RM Bhise. Removal of the colour of the Spent Wash by Activated Charcoal Adsorption and Electro Coagulation.Research Journal of Recent Sciences; 2012,1(6), 66-69.

[6] O Innocent; A Emmanuel; A Thomas. Biosorption of Heavy Metal Ions from Aqueous Solutions Using a Biomaterial.Leonardo Journal of Sciences; 2009,14 (1), 58-65.

[7] S Ong; C Seng; P Lim.Kinetics of adsorption on Cu (II) and Cd (II) from aqueous solution on husk and modified rice husk. Electronic Journal of Environmental, Agricultural and Food Chemistry; 2007.6 (2), 1764-1774.

[8] A Bhattacharya;R Venkobachar.Removal of Cadmium (II) by Low Cost Adsorbents. Journal of Environmental Engineering; 1984,110 (1); 110-122.

[9] Bable, S., Kurniawan, T.A.: Low-cost adsorbent for heavy metals uptake from contaminated water-a review. In: Hazardous Materials. Volume 97 (2003) 219-243.

[10] Ferrari, L., Kaufmann, J., Winnefeld, F., Plank, J.: Interaction of cement model systems with super plasticizers investigated by atomic force microscopy, zeta potential, and adsorption measurements. In: Journal of Colloid Interface Science, Volume 347 (2010) 15-24.

[11] A Erto; RAndreozzi; ALancia;D Musmarra. Factors affecting the adsorption ofTrichloroethylene onto activated carbons. Journal of Applied Surface Science;2010, 256 (3), 5237-5242.

[12] V Leone; S Canzano;P Iovino; S Capasso. Sorption of humic acids by a zeolite feldsparbearing tuff in batch and fixed-bed column. Journal of Porous Materials; 2012,19 (4), 449-453. [13]I. Semra, N. Macit, K. Serpil, and O. Huseyin. Removal of chromium, lead and copper ions from industrial waste water by staphylococcus saprophyticus. Turkish Electronic Journal of Biotechnology. 2:50-57, 2004.

[14] K. Amela, Abdeslam H., and M.D. Kerroum. Isotherm and kinetic study of biosorption of cationic dye onto banana peel. Energy Procedia., 19:286-295, 2012.

[15] M.T. Uddin, M. Rukanuzzaman, M.M.R. Khan, and M.A. Islam. Adsorption of methylene blue from aqueous solution by jackfruit Artocarpusheteropyllus leaf powder: A fixed-bed column study. Journal of Environmental Management, 90(11):3443-3450, 2009. 
[16] Z. Zulfadhly, M.D. Mashitah, and S. Bhatia. Heavy metals removal in fixed-bed column by the macro fungus Pycnoporussanguineus. Journal of Environmental Pollution, 112(3):463-470, 2001.

[17] R. Lakshmipathy and N.C. Sarada. A fixed bed column study for the removal of pb (ii) ions by watermelon rind. Journal of Environ. Sci.: Water Res. Technology, 1:244-250, 2015.

[18] Liu, Z., Li, X., Zhan, P., Hu, F. and Ye, X., 2018. Removal of cadmium and copper from water by a magnetic adsorbent of PFM: adsorption performance and micro-structural morphology.

Separation and Purification Technology, 206, pp.199-207.

[19] Malik, L.A., Bashir, A., Qureashi, A. and Pandith, A.H., 2019. Detection and removal of heavy metal ions: a review. Environmental Chemistry Letters, 17(4), pp.1495-1521.

[20] Maneechakr, P. and Mongkollertlop, S., 2020. Investigation on adsorption behaviors of heavy metal ions $\left(\mathrm{Cd}^{2+}, \mathrm{Cr} 3+, \mathrm{Hg}^{2+}\right.$ and $\left.\mathrm{Pb}^{2+}\right)$ through low-cost/active manganese dioxide-modified magnetic biochar derived from palm kernel cake residue. Journal of Environmental ChemicalEngineering, 8(6), p.104467.

[21] Naseem, K., Begum, R., Wu, W., Usman, M., Irfan, A., Al-Sehemi, A.G. and Farooqi, Z.H., 2019. Adsorptive removal of heavy metal ions using polystyrene-poly (Nisopropylmethacrylamideacrylicacid) core/shell gel particles: adsorption isotherms and kinetic study. Journal of Molecular Liquids, 277, pp.522-531.

[22] Ramdani, A., Kadeche, A., Adjdir, M., Taleb, Z., Ikhou, D., Taleb, S. and Deratani, A., 2020. Lead and Cadmium removal by adsorption process using hydroxyapatite porous materials. Water Practice \&Technology, 15(1), pp.130-141.

[23] Salam, O.E.A., Reiad, N.A. and ElShafei, M.M., 2011. A study of the removal characteristics of heavy metals from wastewater by low-cost adsorbents. Journal of Advanced Research, 2(4), pp.297-

303.

[24] Salishcheva, O.V., Tarasova, Y.V., Lashitskiy, S.S. and Moldagulova, N.E., 2021, February. Analysis of kinetic and equilibrium adsorption of heavy metals by natural materials. In IOP ConferenceSeries: Earth and Environmental Science (Vol. 640, No. 6, p. 062007). IOP Publishing. [25] Samuel, M.S., Selvarajan, E., Subramaniam, K., Mathimani, T., Seethappan, S. and Pugazhendhi, A.,2020. Synthesized $\beta$-cyclodextrin modified graphene oxide $(\beta-C D-G O)$ composite for cadmium adsorption and toxicity profiles in cervical cancer (HeLa) cell lines Process Biochemistry,

93, pp.28-35. 